STUDIA PRAWNO-EKONOMICZNE, t. CIV, 2017

PL ISSN 0081-6841; e-ISSN 2450-8179 s. 101-119

DOI: 10.26485/SPE/2017/104/6

Michał NAJMAN*

\title{
SPECYFIKA ZAWIERANIA UMOWY SEKURYTYZACJI
}

\begin{abstract}
(Streszczenie)
Artykuł odnosi się do pojęcia sekurytyzacji w polskim prawie handlowym. Celem niniejszej publikacji jest przybliżenie etapów upowszechniania się umowy sekurytyzacji w obrocie handlowym, jej charakteru prawnego, ustabilizowanych składników, dopuszczalności przedmiotowej i podmiotowej, praw i obowiązków stron i innych podmiotów uczestniczących w jej zawieraniu, celu gospodarczego, możliwego wpływu na sytuację finansową przedsiębiorstwa będącego stroną umowy sekurytyzacji, a także uświadomienie upowszechnienia się sekurytyzacji w Polsce ze względu na możliwe korzyści jej przeprowadzenia, a co za tym idzie, konieczności uregulowania prawnie jej zawierania. W artykule pominięte zostały szczegółowe kwestie regulacji prawnej przeprowadzenia sekurytyzacji w Polsce ze względu na ich szczątkowość, nadmierny formalizm i niedopasowanie do realiów obecnego obrotu gospodarczego. W zakończeniu autor przedstawia postulaty de lege ferenda co do regulacji prawnej sekurytyzacji w Polsce w nawiązaniu do nieuchwalonego projektu ustawy o sekurytyzacji z 2003 r.
\end{abstract}

Słowa kluczowe: prawo handlowe; sekurytyzacja; dopuszczalność przedmiotowa i podmiotowa sekurytyzacji

\section{Pojęcie umowy sekurytyzacji}

Sekurytyzacja (ang. Security - papier wartościowy) jest umowa, na mocy której inicjator zmienia część swoich wierzytelności (będących aktywami) na papiery wartościowe poprzez odpłatne przekazanie ich SPV (Special Purpose Vehicle), a SPV zobowiązuje się do emisji papierów wartościowych zabezpieczonych tymi wierzytelnościami i ich sprzedaży oraz do zapłaty inicjatorowi za przekazane mu wierzytelności.

* Student IV roku na Wydziale Prawa i Administracji UŁ. Absolwent kierunku Ekonomia na Wydziale Ekonomiczno-Socjologicznym UŁ; e-mail: michalek5558@wp.eu 
Sekurytyzacja rozumiana jest także jako proces ekonomiczny mający na celu uzyskanie środków finansowych ze zbycia wierzytelności przez emisję papierów wartościowych, których wykup zabezpieczają sekurytyzowane wierzytelności ${ }^{1}$. Takie stanowisko przyjmowane jest także w polskim orzecznictwie ${ }^{2}$.

Sekurytyzacja jest to jedna z najprężniej upowszechniających ${ }^{3}$ się w obrocie umów, nienazwanych $\mathrm{w}$ polskim porządku prawnym ${ }^{4}$, jak również forma refinansowania majątku obrotowego przedsiębiorstwa ${ }^{5}$. Wyjaśnić należy, że umowa sekurytyzacji jako umowa nienazwana występuje w obrocie, nie zawiera jednak określonych w ustawie essentialia negotii, ergo za sekurytyzację mogą być uznane umowy różniące się co do elementów istotnych podmiotowo i przedmiotowo; nie jest podobna do umów nazwanych oraz musi być prawnie dopuszczalna na podstawie art. $353^{1}$ ustawy z dnia 23 kwietnia 1964 r. Kodeks cywilny ${ }^{6}$ (dalej jako k.c. $)^{7}$. W praktyce klarują się tzw. składniki ustabilizowane ${ }^{8}$ sekurytyzacji. Są nimi zobowiązanie przeniesienia części aktywów przez inicjatora na SPV, zobowiązanie SPV do wyemitowania papierów wartościowych zabezpieczonych aktywami (ABS - Asset Backed Securities) przeniesionymi na SPV przez inicjatora, zobowiązanie SPV do zapłaty inicjatorowi za przeniesienie aktywów.

Termin ABS stosuje się zbiorczo do instrumentów finansowych zabezpieczonych inaczej niż przez hipotekę 9 . Z kolei instrumenty finansowe (w tym papiery wartościowe) zabezpieczone hipoteką określa się MBS (Mortgage Becked Securities). W początkowym etapie upowszechniania sekurytyzacji jej

1 P. Katner, Sekurytyzacja, w: W.J. Katner (red.), Prawo gospodarcze i handlowe, Wolters Kluwer, Warszawa 2016, s. 696.

2 Uchwała SN z 29 listopada 2007 r., (sygn. III CZP 101/07), OSCN 2008, nr 11, poz. 129; wyrok WSA w Warszawie z 18 lipca 2014 r. (sygn. III SA/Wa 29/14), Lex 1498781 za: P. Katner, op. cit., s. 696.

3 R. Bucholski, Sekurytyzacja aktywów banku hipotecznego, Prace Instytutu Prawa i Administracji PWSZ w Sulechowie, Sulechów 2007/03, s. 33.

4 P. Katner, op. cit., s. 699.

5 A. Bielawska, Sekurytyzacja jako technika refinansowania przedsiębiorstwa, Zeszyty Naukowe Politechniki Koszalińskiej nr 12, Wydawnictwo Politechniki Koszalińskiej, Koszalin 2008, http://zeszyty.wne.tu.koszalin.pl/images/wydawnictwo/zeszyty/02/19.pdf; stan na 1.02.2017 r., s. 1.

6 Dz.U. z 1964 r., nr 16, poz. 93, tekst jedn. Dz.U. z 2016 r., poz. 380.

7 W.J. Katner, Rodzaje umów w obrocie gospodarczym, w: W.J. Katner (red.), Prawo gospodarcze..., s. 402.

8 Ibidem.

9 A. Dąbkowski, Sekurytyzacja - współczesne narzędzie inżynierii finansowej, http://cejsh.icm. edu.pl/cejsh/element/bwmeta1.element.desklight-35608020-06c9-43e1-b14e-392b25eba90a; stan na 1.02.2017 r., s. 10 . 
przedmiotem były przede wszystkim wierzytelności hipoteczne, co spowodowało rozwój sekurytyzacji w tym sektorze, przede wszystkim w krajach anglosaskich, gdzie dodatkowo wyróżnia się CMBS (Commercial Mortgage Becked Securities) - wierzytelności zabezpieczone hipoteką na bazie nieruchomości generujących stałe przychody (np. hotele) i RMBS (Residual Mortgage Becked Securities) - wierzytelności zabezpieczone nieruchomościami, nieprzynoszącymi właścicielom przychodów ${ }^{10}$. W Europie popularne jest zabezpieczenie ABS wierzytelnościami z tytułów kredytów, wierzytelności z tytułu opieki zdrowotnej, umów leasingowych, umów ubezpieczeniowych czy umów franchisingowych. W Polsce popularnością sekurytyzowania cieszą się wierzytelności leasingowe, hipoteczne i samochodowe ${ }^{11}$.

\section{Historia sekurytyzacji}

Po raz pierwszy sekurytyzację przeprowadzono w USA w latach siedemdziesiątych XX w. jako alternatywę pozyskania kapitału w sektorze budownictwa mieszkaniowego. W tym czasie sekurytyzacja była umową o ograniczonej dostępności zarówno przedmiotowej (stosowaną tylko w stosunku do wierzytelności hipotecznych) oraz podmiotowej (korzystały z niej wyłącznie banki). W latach osiemdziesiątych XX w. zaczęto przeprowadzać sekurytyzację innych wierzytelności np. z tytułu płatności leasingowych, należności z kart kredytowych, kredytów samochodowych, kredytów studenckich czy należności handlowych ${ }^{12}$.

W Europie pierwszą sekurytyzację przeprowadzono w 1987 r. w Wielkiej Brytanii ${ }^{13}$. Później umowa ta zaczęła upowszechniać się również we Francji w latach dziewięćdziesiątych XX w. ${ }^{14} \mathrm{~W}$ Europie prawdziwy „boom” sekurytyzacji nastapił w 1996 r., kiedy to zostało przeprowadzone 280 publicznych emisji na łączną kwotę 90 mld USD przez ponad 120 inicjatorów z 11 krajów ${ }^{15}$. Mimo nie-

10 Ibidem.

11 L. Reksa, Sekurytyzacja w krajach Unii Europejskiej oraz w polskim systemie bankowym. Wyniki ankiety badawczej, KNF, Warszawa 2007, s. 48.

12 R. Bucholski, op. cit., s. 3 za: J. Koleśnik, M. Rewieński, Sekurytyzacja wierzytelności bankowych - wybrane aspekty, Prawo Bankowe 2000/7-8, s. 83-84.

13 Ibidem, s. 3.

14 B. Roberts, Pioneering Securitisation in the French Market, w: Z. Shaw (red.), International securitisation. The scope, development and future outlook for asset-backed finance, BerlinLondon 1990, s. 129.

15 L. Reksa, Sekurytyzacja w krajach Unii Europejskiej..., s. 7 na podstawie danych agencji ratingowych oraz banków: DCR, Londyn IFR Securities Data, Londyn CapMac, Londyn ING Baring's. 
wątpliwego sukcesu upowszechnienia się sekurytyzacji (zob. wykres 1), umowa ta nie ma obecnie jednolitej definicji prawnej ${ }^{16}$. Ze względu na znaczną wartość wierzytelności obejmowanych sekurytyzacją, jak i jej popularność w obrocie międzynarodowym podejmowane są próby stworzenia uniwersalnej regulacji sekurytyzacji, jednak wciąż bezowocnie ${ }^{17}$. W Polsce również postuluje się możliwie najbardziej kompleksowe uregulowanie prawne sekurytyzacji ${ }^{18}$, jednak projekt ustawy o sekurytyzacji ${ }^{19}$ nie został uchwalony przez sejm RP. Po przeanalizowaniu opłacalności sekurytyzacji autor wystosuje postulaty de lege ferenda co do definicji legalnej sekurytyzacji, opartej na projekcie ustawy o sekurytyzacji.

WYKRES 1: Roczna wartość emisji instrumentów ABS/MBS w Europie w latach 1987-2005 w mld USD

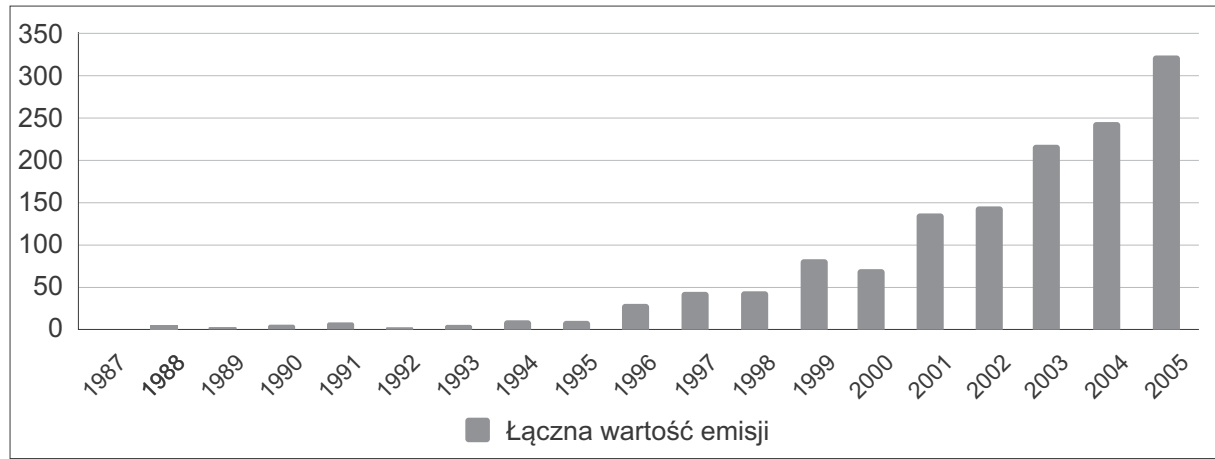

Ź r ó d ł o: L. Reksa, Sekurytyzacja w krajach Unii Europejskiej oraz w polskim systemie bankowym. Wyniki ankiety badawczej, KNF, Warszawa 2007, s. 8.

\section{Podmioty uczestniczące w procesie sekurytyzacji}

Obligatoryjnie w umowie sekurytyzacji występują: inicjator oraz SPV, jak również dłużnicy inicjatora oraz inwestorzy. Fakultatywnie występować może podmiot emisyjny, agencja ratingowa, doradcy, administratorzy lub podmioty ubezpieczające.

\footnotetext{
Ibidem, s. 14-40.
}

17 J. Zombirt, Sekurytyzacja w Bazylei - nadal dużo niewiadomych, Bank 12/2002-1/2003, s. 34-38; J. Zombirt, Sekurytyzacja w Bazylei (cz. II), Bank 2003/2, s. 22-25; J. Zombirt, Sekurytyzacja w Nowej Umowie Kapitałowej, Prawo Bankowe 2003/7-8, s. 41-50.

18 Szerzej: P. Katner, op. cit., s. 699.

19 http://orka.sejm.gov.pl/proc4.nsf druk 2080; stan na 1.02.2017 r. 
Inicjatorem (aranżerem ${ }^{20}$ ) sekurytyzacji może być każdy podmiot posiadający wierzytelności mogące być przedmiotem sekurytyzacji, niezależnie od tego, czy jest to osoba fizyczna, prawna czy jednostka organizacyjna nieposiadająca osobowości prawnej ${ }^{21}$. W praktyce inicjatorem najczęściej będzie profesjonalista (przedsiębiorca/bank). Nieprawidłowe wydaje się ograniczenie podmiotowe, ażeby inicjatorem mógł być wyłącznie przedsiębiorca ${ }^{22}$.

SPV (Special Purpose Vehicle), czyli podmiot specjalnego przeznaczenia, należy uznać za najistotniejszy w umowie sekurytyzacji. To dzięki niemu inicjator „wyzbywa się" ze swojego portfela trudno zbywalnych wierzytelności i zyskuje wynagrodzenie, czyli zyskuje gotówkę, co wpływa pozytywnie na jego płynność finansową lub wypłacalność. Podmiot ten, w przypadku braku regulacji szczególnej, może być dowolny, ale istotne jest, aby charakteryzował się zdolnością do emisji papierów wartościowych ${ }^{23}$.

Niekiedy w umowie sekurytyzacji występuje podmiot emisyjny. Możliwa jest sytuacja, gdy SPV nie będzie miał uprawnień do emisji papierów wartościowych. Wówczas po stronie SPV powstanie zobowiązanie do zobowiązania podmiotu emisyjnego do emisji ABS i ich sprzedaży oraz przekazania przychodów ze sprzedaży SPV lub inicjatorowi. Watpliwość powstaje zatem, czy prawo do zobowiązania podmiotu emisyjnego będzie przysługiwało również inicjatorowi. Rozwiązanie takie wydaje się akceptowalne pod względem prawnym. Wówczas prawnym, wynikającym z umowy obowiązkiem SPV będzie przekazanie wierzytelności otrzymanych od inicjatora na podmiot emisyjny, względnie wykup papierów wartościowych od inwestorów po terminie ich zapadalności i przekazanie uzyskanej sumy pieniężnej inicjatorowi.

Dłużnicy inicjatora są to osoby zobowiązane do świadczenia na rzecz inicjatora. W wyniku sekurytyzacji dochodzi do cesji wierzytelności ${ }^{24}$, czyli zmiany wierzyciela dłużników z inicjatora na SPV. Podlegają oni ochronie na zasadach ogólnych jak przy cesji wierzytelności (art. 509-516 k.c.).

Inwestorzy to podmioty nabywające papiery wartościowe od SPV. Przez nabycie określonych instrumentów finansowych powstaje po ich stronie roszczenie majątkowe o wynagrodzenie w stosunku do SPV. Zaznaczyć należy, że roszczenia te są zabezpieczone roszczeniami SPV w stosunku do dłużników. Powstaje zatem pytanie, czy dopuszczalne jest pominięcie SPV przy realizacji roszczenia

\footnotetext{
A. Dąbkowski, op. cit., s. 5.

Art. 33 i $33^{1}$ k.c.

22 Inaczej: A. Bielawska, op. cit., s. 2.

23 Więcej w części poświęconej ograniczeniom podmiotowym.

${ }^{24}$ Szczególnym przypadkiem jest tu umowa o subpartycypację. Szerzej: P. Katner, op. cit., s. 700.
} 
inwestorów poprzez żądanie świadczenia bezpośrednio od dłużników. Stwierdzić należy, że takie rozwiązanie jest niedopuszczalne. Kreowałoby ono odpowiedzialność solidarną dłużników wobec inwestorów ${ }^{25}$, co znacząco osłabiałoby sytuację prawną dłużników inicjatora. Ponadto wydaje się trudne technicznie do realizacji. Po pierwsze, każdej wierzytelności musiałaby być przyporządkowana ilościowo liczba papierów wartościowych, za które dłużnik odpowiadałby wobec inwestorów. Po drugie, dłużnicy musieliby podlegać wzmożonej ochronie, co wiązałoby się z dodatkowymi nakładami finansowymi, przy i tak kosztownej umowie, jaką jest sekurytyzacja.

W procesie sekurytyzacji występują również inne podmioty. Ich udział nie jest obligatoryjny prawnie. Występowanie opisanych poniżej podmiotów ma jednak istotne znaczenie ze względu na pewność obrotu gospodarczego.

Agencja ratingowa jest podmiotem nadającym rating sekurytyzowanym wierzytelnościom. Każdy podmiot może być agencją ratingową̨ ${ }^{26}$. W praktyce zaufaniem cieszy się zaledwie kilka agencji, jednak ich oceny mają znaczący wpływ na decyzje inwestycyjne. Do najważniejszych i mających największy wpływ na sytuację na rynku finansowym zaliczyć można Standard \& Poor's, Fitch Ratings, Moody's.

Doradcy to podmioty udzielające porad stronom sekurytyzacji. Najczęściej będą to specjaliści (prawnicy, finansiści, doradcy podatkowi etc.). Dopuszczalne, lecz ryzykowne jest także korzystanie z porad nieprofesjonalistów ${ }^{27}$.

Administratorami są podmioty, którym inicjator przekazuje wydzielone już wierzytelności, mające podlegać sekurytyzacji do administrowania.

Podmiotem ubezpieczającym, w zależności od rodzaju zabezpieczenia, może być każdy podmiot (np. przy poręczeniu, przelewie lub przewłaszczeniu na zabezpieczenie) lub podmiot profesjonalny (np. bank przy gwarancji bankowej,

25 Choć w obecnym stanie prawnym brak jest podstaw do powstania takiej odpowiedzialności, w praktyce coraz częściej nabywcy sekurytyzowanych wierzytelności dochodzą swoich roszczeń bezpośrednio od dłużników inicjatora.

26 Pojęcie agencji ratingowej jest szersze od kredytowej agencji ratingowej (credit rating agency) definiowanej w art. 3 ust. 1 lit b rozporządzenia Parlamentu Europejskiego I Rady (WE) nr 1060/2009 z dnia 16 września 2009 r. w sprawie agencji ratingowych (http://eur-lex.europa. eu/legal-content/PL/TXT/HTML/?uri=CELEX:32009R1060\&from=PL; stan na 1.02.2017 r.). Każdy może prowadzić agencję ratingową i rozpowszechniać własne ratingi poszczególnych przedsiębiorstw, o ile działa w dobrej wierze i z poszanowaniem zasad współżycia społecznego.

27 Agencje ratingowe i doradcy nie są podmiotami istotnymi prawnie i nie mają wpływu na ważności umowy sekurytyzacji. 
akredytywie czy ubezpieczeniu bankowym ${ }^{28}$ albo zakład ubezpieczeniowy lub partner swapowy $\left.{ }^{29}\right)^{30}$.

Pamiętać jednak należy, że przedmiotem sekurytyzacji zazwyczaj są wierzytelności o znacznej wartości (od kilku do kilkuset milionów), co wymusza konieczność wprowadzenia podmiotów kontrolujących lub nadzorujących, jak również zabezpieczających, doradczych, koordynujących lub administrujących. Uczestnictwo innych profesjonalnych podmiotów przy zawieraniu sekurytyzacji pełni funkcję gwarancyjną zarówno dla dłużników, jak i inwestorów, a także zapewnia optymalizację realizacji zasady pewności obrotu.

\section{Charakter prawny i treść umowy sekurytyzacji}

Umowa sekurytyzacji jest umową wielostronną inter vivos ${ }^{31}$, kauzalną (causa obligandi vel acquirendi, względnie causa fiducie), konsensualną, wzajemnie zobowiązującą i odpłatną. Podkreślić trzeba, że jest to umowa co najmniej jednostronnie profesjonalna ${ }^{32}$.

W najprostszym wariancie przez zawarcie umowy sekurytyzacji strony kreuja stosunek obligacyjny, zgodnie z którym inicjator zobowiązuje się do przeniesienia odpłatnie części aktywów na SPV, a SPV zobowiązuje się do emisji i sprzedaży papierów wartościowych zabezpieczonych przeniesionymi na nią aktywami (ABS) oraz do zapłaty wynagrodzenia inicjatorowi w zamian za przeniesienie na nią aktywów.

Można wyróżnić następujące etapy sekurytyzacji:

1) wydzielenie przez inicjatora wierzytelności podlegających sekurytyzacji,

2) utworzenie SPV lub znalezienie istniejącego już podmiotu chętnego do przystapienia do umowy,

28 Szerzej: W.J. Katner, Zabezpieczenie wierzytelności umownej, w: W.J. Katner (red.), Prawo gospodarcze..., s. 431-440.

29 Umowa swapu ma na celu ograniczenie ryzyka zmiany stopy oprocentowania lub ryzyka walutowego. Ma charakter nienazwany i wzajemny. Można wyróżnić swap procentowy lub walutowy. Szerzej: A. Adamek, Umowy pomocnicze zawierane w ramach procesu sekurytyzacji, Lex 69497.

30 A. Adamek, Podmioty uczestniczace w procesie sekurytyzacji, Lex 69492.

31 Choć umowy mortis causa co do zasady zastrzeżone są dla osób fizycznych, możliwa jest sytuacja, gdy znajdą one zastosowanie w stosunku do osób prawnych przy odpowiednim stosowaniu przepisów. W przypadku sekurytyzacji umowa taka może mieć następującą treść: inicjator zobowiązuje się wobec SPV, że w razie ogłoszenia jego upadłości przekaże na niego określone wierzytelności, z kolei SPV zobowiązuje się do emisji papierów wartościowych zabezpieczonych przekazanymi mu wierzytelnościami od inicjatora i zaspokojenia wierzycieli inicjatora. W przypadku tym zawsze należy zbadać, czy umowa taka nie narusza art. 5 k.c.

32 Patrz: dopuszczalność przedmiotowa. 
3) zobowiązanie inicjatora do odpłatnego przeniesienia na SPV wydzielonych wierzytelności,

4) zobowiązanie SPV do emisji papierów wartościowych zabezpieczonych przenoszonymi wierzytelnościami (ABS),

5) przeniesienie wierzytelności przez inicjatora na SPV,

6) emisja papierów wartościowych przez SPV,

7) sprzedaż papierów wartościowych przez SPV,

8) przekazanie przychodów ze sprzedaży inicjatorowi przez SPV,

9) ściagnięcie długów przez SPV od dłużników inicjatora,

10) wykup sprzedanych papierów wartościowych przez SPV po terminie zapadalności ${ }^{33}$.

\section{Prawa i obowiązki stron}

Prawami i obowiązkami inicjatora są:

1) prawo do wynagrodzenia za przeniesienie wierzytelności od SPV,

2) obowiązek wydzielenia i przeniesienia wierzytelności na SPV,

3) obowiązek odebrania zapłaty od SPV, w szczególności gdy SPV zobowiązany jest świadczyć w sposób inny niż pieniężny (np. przeniesienie własności rzeczy).

Prawami i obowiązkami SPV są:

1) uprawnienie żądania przeniesienia na niego wierzytelności, do których przeniesienia zobowiązał się inicjator,

2) obowiązek zapłaty za przeniesienie wierzytelności,

3) obowiązek odbioru cedowanych wierzytelności,

4) obowiązek emisji ABS,

5) obowiązek sprzedaży ABS,

6) obowiązek odsprzedaży ABS od inwestorów ${ }^{34}$.

Dłużnicy mają obowiązek spełnienia świadczenia należnego inicjatorowi na rzecz SPV, a w niektórych przypadkach prawo zakwestionowania sekurytyzacji (np. przy niskiej nocie ratingowej). Inwestorzy mają obowiązek zapłaty i odbio$\mathrm{ru}^{35} \mathrm{ABS}$ od SPV (albo emitenta) oraz prawo żądania wykupu zakupionych przez nich instrumentów finansowych przez SPV (lub emitenta), po upływie terminu zapadalności.

33 Propozycja autora.

34 Propozycja autora.

35 Jeżeli papiery są w formie materialnej. Obecnie powszechniejszy jest obrót papierami w postaci zdematerializowanej, w związku z czym odbiór następuje za pomocą systemu teleinformatycznego. 
SCHEMAT 1: Uproszczony model procesu sekurytyzacji

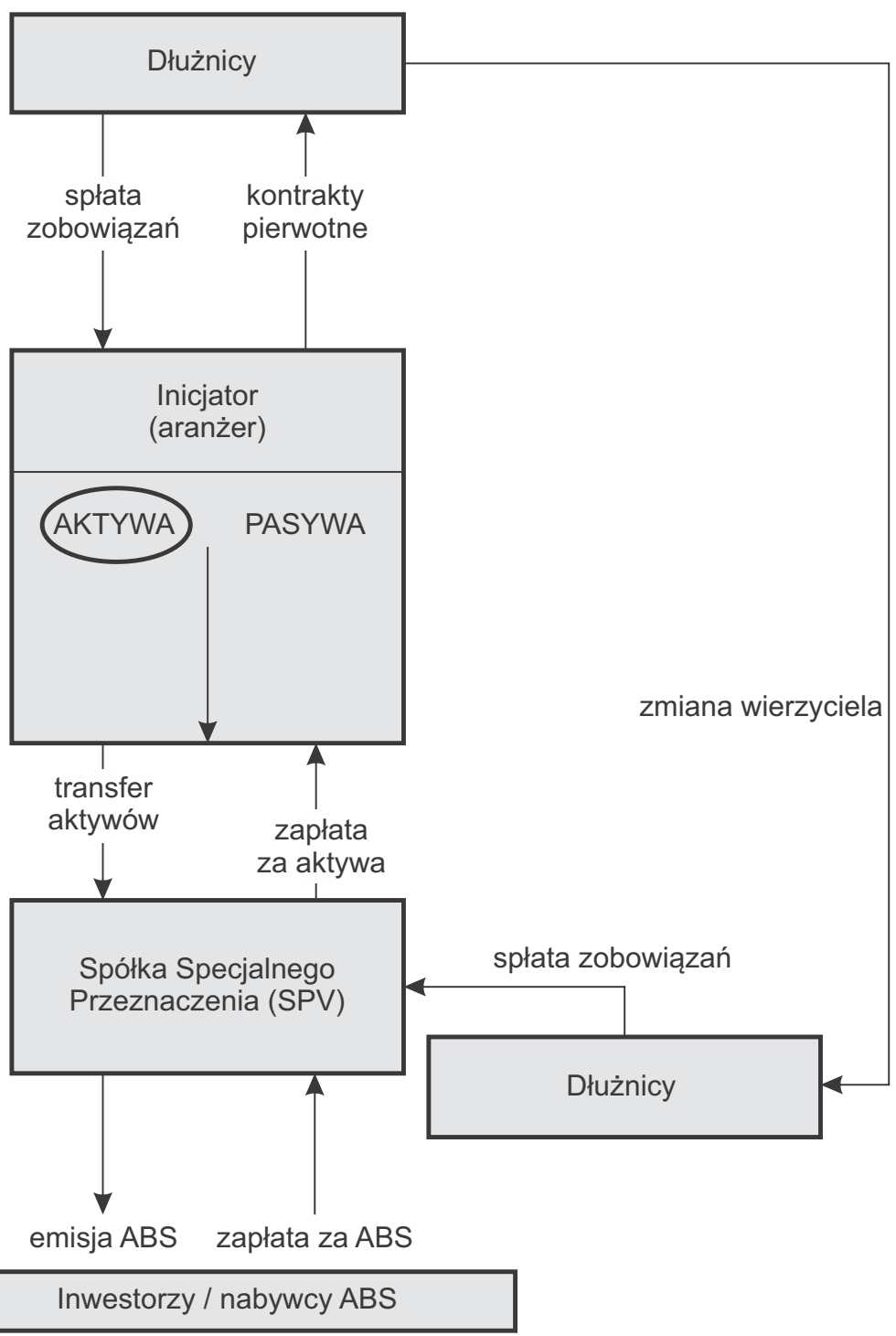

Źr ó dło: opracowanie własne na podstawie: A. Bielawska, Sekurytyzacja jako technika refinansowania przedsiębiorstwa, Zeszyty Naukowe Politechniki Koszalińskiej nr 12, Wydawnictwo Politechniki Koszalińskiej, Koszalin 2008, s. 3. 
W praktyce modele sekurytyzacji są bardzo rozbudowane (zob. schemat 2). W wielu krajach UE, m.in. przez złożoność procesu sekurytyzacji, uregulowane są wymagania podmiotowo-przedmiotowe co do poszczególnych etapów i uczestników realizacji umowy. Model uproszczony ma raczej charakter dydaktyczny i rzadko występuje w praktyce. Pamiętać jednak należy, że wymagania co do wartości sekurytyzowanych wierzytelności nie mają charakteru normatywnego, a więc umowa sekurytyzacji może być zawierana także dla wierzytelności o mniejszych wartościach ${ }^{36} \mathrm{i}$ będzie ona ważna i skuteczna.

SCHEMAT 2: Model zaawansowany procesu sekurytyzacji

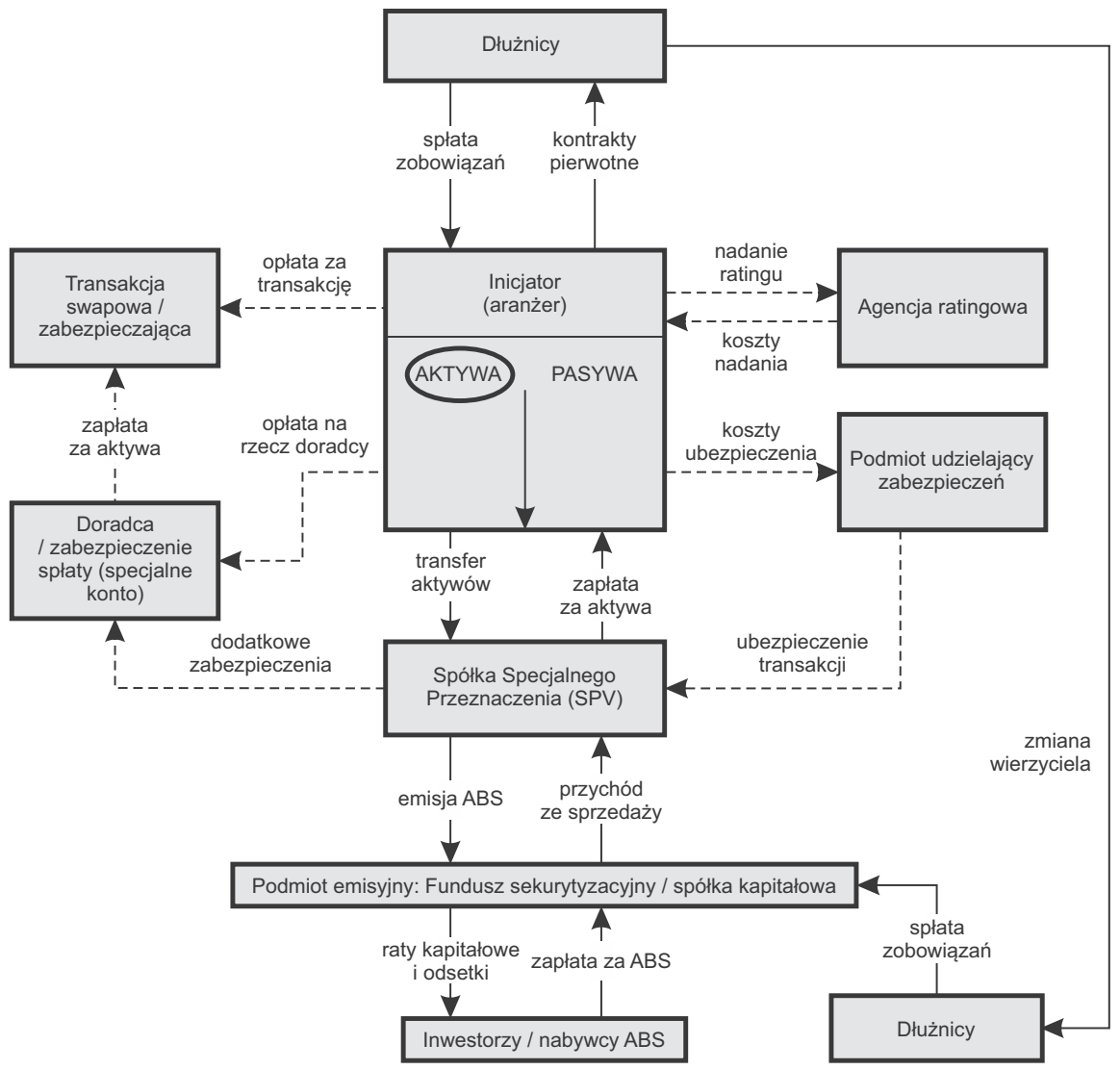

Ź ró d ł o: opracowanie własne na podstawie: A. Bielawska, op. cit., s. 3.

36 Mogą to być również pakiety wierzytelności konsumenckich. 


\section{Ogólny zarys regulacji prawnej}

W krajach, gdzie rynek finansowy jest głównym wytwórcą ${ }^{37} \mathrm{PKB}$, jak Wielka Brytania, Francja czy Holandia regulacja prawna sekurytyzacji jest bardziej szczegółowa niż w krajach słabiej rozwiniętych, jak Polska ${ }^{38}$.

W Polsce regulacja prawna sekurytyzacji jest szczątkowa. Jak wskazuje P. Katner ${ }^{39}$, odnoszą się do niej: art. 92a, 92d ustawy z dnia 29 sierpnia $1997 \mathrm{r}$. - Prawo bankowe ${ }^{40}$ oraz kilka przepisów ustawy z dnia 27 maja 2004 r. o funduszach inwestycyjnych i zarządzaniu alternatywnymi funduszami inwestycyjnymi ${ }^{41}$. Występuje wiele ograniczeń proceduralno-podmiotowych ${ }^{42}$.

Umowa sekurytyzacji, jak się wydaje, nie zmierza do obejścia prawa, nie jest sprzeczna z prawem ani dobrymi obyczajami i nie sprzeciwia się naturze stosunku pierwotnego między inicjatorem a jego dłużnikami ${ }^{43}$. Kwestią sporną jest przede wszystkim ochrona dłużników, jak w każdym przypadku cesji wierzytelności, a także ochrona SPV przed niewypłacalnością dłużników. W polskiej regulacji kwestia ochrony dłużników przy zmianie wierzyciela regulowana jest w art. 512 do 515 k.c., a ochrony SPV w art. 516 k.c. Względnie stosować można art. 517 k.c., albo uznać regulację kodeksową jako dyspozytywną w stosunku do sekurytyzacji i stosować przepisy umowne, o ile nie zmierzają do obejścia prawa.

\section{Dopuszczalność podmiotowa}

W doktrynie przyjmuje się, że nie istnieje ograniczenie odnośnie do tego, kto może być inicjatorem. Musi to być podmiot dysponujący zbywalnymi wierzytelnościami. W praktyce będzie to zazwyczaj profesjonalista (przedsiębiorca, w szczególności bank).

Inaczej wygląda kwestia nabywcy wierzytelności (SPV) w drodze sekurytyzacji. Jest tu ograniczona swoboda możliwości bycia podmiotem specjalnego

37 P. Krugman, Macroeconomics, Worth Publishers, 2015, s. 51-58.

38 L. Reksa, Sekurytyzacja w krajach Unii Europejskiej..., s. 15-40; A. Dąbkowski, op. cit., s. 23.

9 P. Katner, op. cit., s. 699.

Dz.U. z 1997 r., nr 140, poz. 939, tekst jedn. Dz.U. z 2016 r., nr 0, poz. 1988.

1 Dz.U. z 2004 r., nr 146, poz. 1546, tekst jedn. Dz.U. z 2016 r., nr 0, poz. 1896.

42 A. Bielawska, op. cit., s. $2-7$.

$43 \mathrm{~W}$ praktyce pojawiają się jednak zjawiska patologiczne polegające na zawieraniu przez inicjatora z dłużnikami umów, pomimo ich niewypłacalności, a następnie sekurytyzowanie wierzytelności wobec tych dłużników. Zob. https://biznes.newseria.pl/komunikaty/bankowosc/trudne-zycie-funduszy,b2019726180; stan na 1.02.2017 r.). 
przeznaczenia. Istnieje różnorodność dopuszczalności do bycia SPV w ustawodawstwach światowych. Na przykład w Wielkiej Brytanii SPV najczęściej jest to trust, w Niemczech spółka lub fundacja, z kolei we Francji utworzono specjalny podmiot FCC (Fond Communs de Créances) ${ }^{44}$. W polskiej regulacji wykreowano fundusz sekurytyzacyjny ${ }^{45}$. Jak wskazuje A. Adamek: ,[...] najważniejszą cechą omawianego podmiotu zwanego SPV, [...] jest znikoma skłonność do upadłości (ang. bankruptcy remotness). Z tego założenia wynikają następujące powtarzające się w różnych porządkach prawnych rozwiązania:

- konieczność zapewnienia szeroko rozumianej niezależności SPV od inicjatora, polegającej przynajmniej na tym, że SPV nie powinno być spółką-córką inicjatora czy też posiadać takiej samej lub podobnej nazwy;

- zakaz prowadzenia przez SPV działalności innej niż sekurytyzacyjna w celu ograniczenia ryzyka wynikającego z przedsięwzięć mogących skutkować niewypłacalnością SPV;

- zakaz zatrudniania pracowników lub ograniczenie ich do minimum, aby zminimalizować zobowiązania SPV jako podmiotu mającego jedynie istnieć w sensie prawnym jako pośrednik pomiędzy inicjatorem a inwestorem, czyli podmiotami, którym mają przypaść zasadnicze korzyści całego procesu;

- ustalenie dodatkowych zasad odpowiedzialności SPV w sytuacji, gdy jest on podmiotem pośredniczącym w więcej niż jednym procesie sekurytyzacyjnym"46.

Inwestorem i dłużnikiem może być każdy podmiot (osoba fizyczna, osoba prawna lub tzw. ułomna osoba prawna). Umowa sekurytyzacji co do zasady nie kreuje roszczeń między inwestorami a dłużnikami (np. w przypadku niewypłacalności SPV), choć uznać należy dopuszczalność takiego rozwiązania w postanowieniach umowy ${ }^{47}$.

\section{Dopuszczalność przedmiotowa}

Można wyróżnić dwa przedmioty umowy sekurytyzacji: zbywane przez inicjatora wierzytelności (przedmiot pierwotny) oraz emitowane przez SPV papiery wartościowe (przedmiot wtórny).

44 A. Adamek, Podmioty uczestniczące...

45 Więcej na temat funduszu sekurytyzacyjnego: ibidem.

46 Ibidem.

$47 \mathrm{~Np}$. w przypadku cesji wierzytelności SPV wobec inwestorów/podmiotu emisyjnego na inicjatora lub fuzji SPV i inicjatora. 
Co do wierzytelności przyjmuje się, że powinny być to wierzytelności pieniężne, zbywalne i możliwie jednorodne ${ }^{48}$, istniejące lub przyszłe ${ }^{49}$. Za zbyt liberalny uznać należy pogląd, ażeby przedmiotem sekurytyzacji mogło być „wszystko, co ma jakąkolwiek wartośc [i] może w przyszłości przynosić dochody odsetkowe" ${ }^{50}$. Ponadto wskazuje się, że wydzielane wierzytelności powinny być bezsporne i oznaczalne, a także gwarantować wpływy pieniężne w przyszłości, możliwe do ustalenia na dzień zawarcia umowy ${ }^{51}$.

A. Bielawska ${ }^{52}$ wyróżnia dodatkowe kryterium dopuszczalności ${ }^{53}$ wierzytelności do sekurytyzacji. Jest nim kryterium wartości pieniężnej sekurytyzowanych wierzytelności. Wskazuje ona, że wartość ta powinna wynosić co najmniej $20 \mathrm{mln}$ euro, powołując się na literaturę niemiecka, jednak bez wskazania konkretnej publikacji. W polskich realiach podaje co najmniej 500 tys. zł w przypadku utworzenia SPV w formie spółki akcyjnej i 50 tys. zł w formie spółki z o.o. oraz dodatkowe koszty w postaci doradztwa ok. 60 tys. zł, koszty ustalenia noty ratingowej ok. 100 tys. zł rocznie oraz premię dla przyszłych inwestorów ${ }^{54}$. Kwoty te, jak na standardy światowe $\mathrm{e}^{55}$, wydają się rażąco niskie i wątpliwe jest, aby transakcje o tak relatywnie niewielkiej wartości były opłacalne. Jednak zaznaczyć należy, że podane wyżej kwoty są umowne, zatem możliwe jest zawarcie umowy sekurytyzacji przy cesji wierzytelności o mniejszej wartości. W tym przypadku wattpliwa pozostaje jednak opłacalność tego przedsięwzięcia.

Inaczej wygląda możliwość (dopuszczalność) emisji papierów wartościowych na podstawie zobowiązania z umowy sekurytyzacji przez SPV $(A B S)$. Papiery wartościowe mają definicję legalną w art. 3 pkt 1 lit. a i b w zw. z art. 2 ustawy z dnia 29 lipca 2005 r. o obrocie instrumentami finansowymi ${ }^{56}$. Za papier wartościowy uznaje się akcje, prawa poboru, prawa do akcji, warranty subskrypcyjne, kwity depozytowe, obligacje, listy zastawne, certyfikaty inwestycyjne i inne zbywalne papiery wartościowe, $w$ tym inkorporujące prawa majątkowe odpowiadające prawom wynikającym z akcji lub z zaciaggnięcia długu, wyemitowane na podstawie

48 J. Grodzicki, R.W. Kaszubski, Sekurytyzacja - aspekty prawne, Glosa 1999, nr 8, s. 4.

49 L. Reksa, Sekurytyzacja wierzytelności na rynkach międzynarodowych, Bank i Kredyt, luty 2004, s. 65.

50 Ibidem, s. 62.

51 R. Bucholski, op. cit., s. 42; szerzej: A. Dąbkowski, op. cit., s. 16-21.

52 A. Bielawska, op. cit., s. 6.

53 Jest to przesłanka ekonomiczna. Jej brak nie ma wpływu na ważność i skuteczność umowy sekurytyzacji.

54 A. Bielawska, op. cit., s. 6-7.

55 Ibidem, s. 7.

56 Dz.U. z 2005 r., nr 183, poz. 1538, tekst jedn. Dz.U. z 2016 r., nr 0, poz. 1636. 
właściwych przepisów prawa polskiego lub obcego, a także prawa pochodne. $\mathrm{Z}$ definicji tej wynika, że SPV musi być profesjonalistą, tj. przedsiębiorcą uprawnionym do emisji wskazanych wyżej instrumentów finansowych, czyli spółką akcyjną, spółką z o.o. lub spółką komandytowo-akcyjną albo kasą spółdzielczo-oszczędnościową, jednostką samorządu terytorialnego, Skarbem Państwa czy inną instytucją finansową uprawnioną do emisji papierów wartościowych na podstawie przepisów szczególnych ${ }^{57}$. Zaznaczyć należy, że w przypadku, gdy inwestorem jest konsument, nie korzysta on $\mathrm{z}$ ochrony na podstawie przepisów szczególnych, gdyż nie stosuje się ich do obrotu papierami wartościowymi.

\section{Cel umowy}

Celem gospodarczym każdej umowy handlowej jest, co oczywiste, wystąpienie korzyści dla wszystkich uczestników umowy sekurytyzacji ${ }^{58}$. Można mówić o szeregu korzyści dla poszczególnych uczestników sekurytyzacji (zob. tabela 1). Podmioty uczestniczące w sekurytyzacji można podzielić na trzy grupy, przyjmując za kryterium osiagane korzyści. W pierwszej grupie znajduje się inicjator, który zyskuje wiele profitów, jakie niesie za sobą sekurytyzacja, w tym m.in.: zyskuje dodatkowe źródło finansowania działalności, wyzbywa się trudno zbywalnych wierzytelności czy poprawia płynność finansową ${ }^{59}$. Do drugiej grupy zaliczyć należy inwestorów, ubezpieczycieli, doradców i agencje ratingowe będące podmiotami, które zyskują korzyści majątkowe ${ }^{60}$. Trzecią grupę stanowią podmioty, które co do zasady nie odnoszą korzyści z przeprowadzenia sekurytyzacji. Sa to SPV oraz dłużnicy inicjatora. Zaznaczyć należy, iż w zależności od tego, czy SPV jest podmiotem utworzonym wyłącznie w celu realizacji sekurytyzacji (zależnym ${ }^{61}$ od inicjatora), czy samodzielnym podmiotem prowadzącym działalność gospodarczą może być zaliczony do wskazanej powyżej grupy drugiej lub trzeciej (zob. tabela 1).

57 M.in. ustawa z dnia 15 stycznia 2015 r. o obligacjach (Dz.U. z 2015 r., poz. 238); ustawa z 15 września 2000 r. Kodeks spółek handlowych (Dz.U. z 2000 r., nr 94, poz. 1037, tekst jedn. Dz.U. z 2016 r., nr 0, poz. 1578) [dalej jako k.s.h.].

58 W.J. Katner, op. cit., s. 401-402.

59 Więcej na temat korzyści ekonomicznych i finansowych z sekurytyzacji dla inicjatora: J. Deacon, Global Securitisation and CDOs, John Wiley \& Sons, Ltd., 2003, s. 5; S.L. Schwarcz, The Alchemy of Asset Securitization, Stanford Journal of Law, Business \& Finance Fall 1994/1/1, s. 137.

${ }^{60}$ Szerzej: J. Lizińska, Przesłanki wykorzystywania sekurytyzacji aktywów w procesie finansowania przedsiębiorstwa, Ruch Prawniczy, Ekonomiczny i Socjologiczny 2005/LXVII/3, s. $194-198$.

${ }^{61}$ Art. 6 w zw. z art. 4 ust. 4 k.s.h. 
TABELA 1: Korzyści, jakie odnoszą uczestnicy procesu sekurytyzacji

\begin{tabular}{|c|c|}
\hline Podmiot & Korzyści \\
\hline Inicjator & 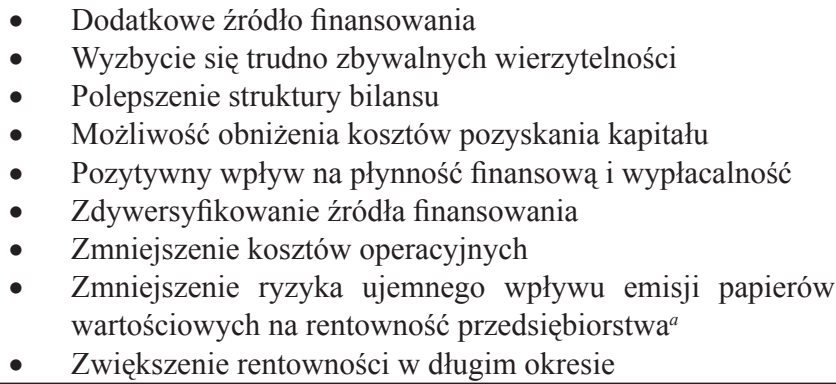 \\
\hline SPV & $\begin{array}{l}\text { - } \\
\text { - } \\
\text { * Cena korzyści }{ }^{b} \\
\text { niższa od ich rzeczecywistej wartości, zatem korzyścią dla SPV } \\
\text { jest korzyść majątkowa }{ }^{c}\end{array}$ \\
\hline Dłużnicy & - $\quad$ Brak korzyści \\
\hline Inwestorzy & - $\quad$ Korzyści majątkowe \\
\hline Podmiot ubezpieczający & - $\quad$ Korzyści majątkowe \\
\hline Doradcy & - Korzyści majątkowe \\
\hline
\end{tabular}

a M. Kędzior, Zależność rentowności przedsiębiorstw od czynników mikroekonomicznych i makroekonomicznych i instytucjonalnych $w$ wybranych państwach Unii Europejskiej, Wydawnictwo Uniwersytetu Ekonomicznego w Krakowie, Kraków 2016, s. 118.

${ }_{b}$ Korzyści w ogóle nie muszą wystąpić. Wynika to z charakteru SPV, tj. podmiotu utworzonego tylko po to, aby upłynnić część aktywów inicjatora.

c Zasadą jest, że SPV nie musi osiaggá korzyści. Często jest to spółka całkowicie zależna od inicjatora, która ma minimalizować ryzyko kredytowe i zmniejszać koszt pozyskania kapitału. Szerzej: J. Lizińska, Przesłanki wykorzystywania sekurytyzacji aktywów w procesie finansowania przedsiębiorstwa, Ruch Prawniczy, Ekonomiczny i Socjologiczny 2005/LXVII/3, s. 193-194.

Źr ódło: opracowanie własne.

Sekurytyzacja jest umową niezwykle kapitałochłonną. Wymaga zatem starannego przygotowania. Wiążą się z tym koszty doradztwa, zabezpieczeń i wynagrodzeń dla pozostałych uczestników. Zagrożenie dla sekurytyzacji pojawia się już w procesie planowania, gdyż nieprofesjonalne sekurytyzowania wierzytelności (np. łatwo zbywanych) może przyczynić się do obniżenia przychodów inicjatora i w konsekwencji okazać „metodą nieefektywnego, kosztownego refinansowania" ${ }^{62}$.

${ }^{62}$ A. Bielawska, op. cit., s. 8. 


\section{Umowa o subpartycypację}

Szczególnym rodzajem sekurytyzacji jest umowa o subpartycypację ${ }^{63}$. Jej konstrukcja jest podobna do sekurytyzacji z tym wyjątkiem, że nie dochodzi do zmiany wierzyciela sekurytyzowanych wierzytelności. W przypadku sekurytyzacji wierzycielem staje się SPV, a przestaje nim być inicjator. W subpartycypacji powstaja takie same prawa i obowiązki po stronie SPV i inicjatora (i innych uczestników procesu) jak w sekurytyzacji, z wyjątkiem roszczenia SPV o przeniesienie na niego wierzytelności i obowiązku inicjatora do ich przeniesienia. Rozwiązanie nie wydaje się być korzystne dla usprawnienia obrotu, w szczególności gdy wierzytelności sekurytyzowane objęte są klauzulą wyłączającą zbywalność (tzw. pactum de non cedendo ${ }^{64}$ ). Słusznie zaznacza P. Katner, iż jest to umowa nazwana w polskim porządku prawnym ${ }^{65}$, w związku z czym uznawać należy ją za oddzielną umowę, a nie część lub szczególny rodzaj umowy sekurytyzacji ${ }^{66}$.

Subpartycypację odróżnić należy od sposobu zawierania umowy sekurytyzacji, jak się niekiedy przyjmuje ${ }^{67}$. Wyróżnia się dwa sposoby zawarcia tej umowy: pierwszym jest sprzedaż (true sale) - tzw. sekurytyzacja przez sprzedaż, drugim przeniesienie ryzyka niewypłacalności dłużników z cedowanych wierzytelności ${ }^{68}$. Subpartycypacja to oddzielna umowa cywilnoprawna ${ }^{69}$.

\section{Zakończenie}

Sekurytyzacja jest umową wpływającą na rentowność przedsiębiorstwa w długim okresie. W prawie polskim jest to umowa nienazwana, co wpływa niekorzystnie na jej upowszechnienie $\mathrm{w}$ obrocie. Postulatem autora de lege ferenda jest

63 Inaczej - jako tryb zawarcia sekurytyzacji: A. Dąbkowski, op. cit., s. 22, L. Reksa, Sekurytyzacja wierzytelności na rynkach..., s. 67-69.

64 Za: P. Katner, op. cit., s. 700. Zawarcie umowy sekurytyzacji podczas gdy wierzytelności sekurytyzowane objęte są pactum de non cedendo powoduje jej bezskuteczność.

65 Ibidem, s. 700.

66 Inaczej: P. Katner, op. cit., s. 700; K. Haladyj, Sekurytyzacja-potrzeba zmian, Przegląd Prawa Handlowego, marzec 2007, s. 44.

67 Inaczej: https://alebank.pl/zielone-swiatlo-dla-subpartycypacji-w-bankach/?id=38578\&catid $=625$; stan na 1.02.2017 r.).

68 SPV otrzymuje wynagrodzenie od inicjatora za przejęte ryzyko, a za zysk z wyemitowanych papierów wartościowych (CLO/CMO) nabywa inne papiery wartościowe o mniejszym ryzyku. Z wynagrodzenia zaspokajani są inwestorzy. Szerzej: A. Dąbkowski, op. cit., s. 13.

69 Szerzej na temat subpartycypacji: K. Haladyj, Umowa Subpartycypacji-zagadnienia konstrukcyjne, Prawo Bankowe 2007/2, s. 90. 
następujące brzmienie definicji legalnej sekurytyzacji w oddzielnej umowie lub w k.s.h.: „Przez umowę sekurytyzacji inicjator zobowiązuje się do przekazania podmiotowi uprawnionemu do emisji papierów wartościowych (emitentowi) wierzytelności ${ }^{70}$ za wynagrodzeniem, a emitent zobowiązuje się do emisji papierów wartościowych zabezpieczonych wierzytelnościami przekazanymi mu przez inicjatora, ich sprzedaży oraz przekazania inicjatorowi środków uzyskanych ze sprzedaży, a także spełnienie zobowiązań wynikających z wyemitowanych papierów wartościowych". Sekurytyzacja jest zatem umową inter vivos, kauzalna, konsensualną, odpłatną i wzajemnie zobowiązująca. Ze względu na jej doniosłość ekonomiczną powinna być zawierana w formie aktu notarialnego, co nie zostało zauważone w projekcie ustawy o sekurytyzacji ${ }^{71}$. Zaznaczyć należy, iż upowszechnienie sekurytyzacji w dużej mierze zależy od stopnia rozwoju rynku kapitałowego w danym państwie i jego udziału w PKB oraz zapewnieniu pewności obrotu poprzez m.in. prawne uregulowanie sekurytyzacji w możliwie jak najmniej sformalizowany sposób.

\section{Bibliografia}

\section{Akty prawne}

Ustawa z dnia 23 kwietnia 1964 r. Kodeks cywilny (Dz.U. z 1964 r., nr 16, poz. 93, tekst jedn. Dz.U. z 2016 r., poz. 380).

Ustawa z 15 września 2000 r. Kodeks spółek handlowych (Dz.U., z 2000 r., nr 94, poz. 1037, tekst jedn. Dz.U. z 2016 r., nr 0, poz. 1578).

Ustawa z dnia 15 stycznia 2015 r. o obligacjach (Dz.U. z 2015 r., poz. 238).

Ustawa z dnia 29 lipca 2005 r. o obrocie instrumentami finansowymi (Dz.U. z 2005 r., nr 183, poz. 1538, tekst jedn. Dz.U. z 2016 r., nr 0, poz. 1636).

$70 \mathrm{~W}$ projekcie ustawy o sekurytyzacji (http://orka.sejm.gov.pl/proc4.nsf druk 2080; stan na 1.02.2017 r.) zamiast wierzytelności postuluje się prawa majątkowe, jednak wydaje się zbyt daleko idące i stwarzające ryzyko w postaci niewypłacalności podmiotu zobowiązanego do emisji papierów wartościowych w przypadku niewypłacalności inicjatora (np. przy przeniesieniu własności). Problem dotyczy również możliwości wystosowania w takim przypadku powództwa pauliańskiego. Szerzej o dopuszczalności actio pauliana przeciwko inicjatorowi sekurytyzacji pisze się m in. w Portugalii (P. Malaquias, S. Borges, Securitisation under the Portuguese Securitisation Law, w: The international comparative legal guide to securitisation 2005, GLG, 2005, s. 199), gdzie przyjmuje się, iż wierzycielom inicjatora sekurytyzacji przysługuje skarga pauliańska, jeżeli zachowanie inicjatora i SPV spełniają dyspozycję przewidzianą w przepisach o tym powództwie. Rozwiązanie to wydaje się możliwe do zastosowania również w Polsce.

71 http://orka.sejm.gov.pl/proc4.nsf druk 2080; stan na 1.02.2017 r. 
Ustawa z dnia 27 maja 2004 r. o funduszach inwestycyjnych i zarządzaniu alternatywnymi funduszami inwestycyjnymi (Dz.U. z 2004 r., nr 146, poz. 1546, tekst jedn. Dz.U. z 2016 r., nr 0, poz. 1896).

Ustawa z dnia 29 sierpnia 1997 r. - Prawo bankowe (Dz.U. z 1997 r., nr 140, poz. 939, tekst jedn. Dz.U. z 2016 r., nr 0, poz. 1988).

Uchwała SN z 29 listopada 2007 r., (sygn. III CZP 101/07), OSCN 2008, nr 11, poz. 129; wyrok WSA w Warszawie z 18 lipca 2014 r. (sygn. III SA/Wa 29/14).

Rozporządzenia Parlamentu Europejskiego i Rady (WE) nr 1060/2009 z dnia 16 września 2009 r. w sprawie agencji ratingowych, http://eur-lex.europa.eu/legal-content/PL/TXT/HTML/?uri$=$ CELEX:32009R1060\& from=PL; stan na 1.02.2017 $\mathrm{r}$.

\section{Opracowania}

Adamek Artur, Podmioty uczestniczace w procesie sekurytyzacji, Lex 69492.

Adamek Artur, Umowy pomocnicze zawierane w ramach procesu sekurytyzacji, Lex 69497.

Bielawska Aurelia, Sekurytyzacja jako technika refinansowania przedsiębiorstwa, Zeszyty Naukowe Politechniki Koszalińskiej nr 12, Wydawnictwo Politechniki Koszalińskiej, Koszalin 2008.

Bucholski Rafal, Sekurytyzacja aktywów banku hipotecznego, Prace Instytutu Prawa i Administracji PWSZ w Sulechowie, Sulechów 2007, s. 33-56.

Dąbkowski Andrzej, Sekurytyzacja - współczesne narzędzie inżynierii finansowej, http://cejsh. icm.edu.pl/cejsh/element/bwmeta1.element.desklight-35608020-06c9-43e1-b14e-392b25eba90a; stan na 1.02.2017 r.

Deacon John, Global Securitisation and CDOs, John Wiley \& Sons, Ltd., 2003.

Grodzicki Jędrzej, Kaszubski Remigiusz Witold, Sekurytyzacja - aspekty prawne, Glosa 1999, nr 8.

Haładyj Krzysztof, Sekurytyzacja - potrzeba zmian, Przegląd Prawa Handlowego 2007/3, s. 43-50.

Haładyj Krzysztof, Umowa subpartycypacji - zagadnienia konstrukcyjne, Prawo Bankowe 2007/2, s. 87-94.

Katner Przemysław, Sekurytyzacja, w: Wojciech J. Katner (red.), Prawo gospodarcze i handlowe, Wolters Kluwer, Warszawa 2016, s. 696-703.

Katner Wojciech J., Zasada swobody umów i jej granice; Rodzaje umów w obrocie gospodarczym (umów handlowych), w: Wojciech J. Katner (red.), Prawo gospodarcze $i$ handlowe, Wolters Kluwer, Warszawa 2016, s. 398-402.

Kędzior Marcin, Zależność rentowności przedsiębiorstw od czynników mikroekonomicznych i makroekonomicznych i instytucjonalnych $w$ wybranych państwach Unii Europejskiej, Wydawnictwo Uniwersytetu Ekonomicznego w Krakowie, Kraków 2016.

Koleśnik Jan, Rewieński Maciej, Sekurytyzacja wierzytelności bankowych - wybrane aspekty, Prawo Bankowe 2000/7-8, s. 81-96.

Krugman Paul R., Macroeconomics, Worth Publishers, 2015.

Lizińska Joanna, Przesłanki wykorzystywania sekurytyzacji aktywów w procesie finansowania przedsiębiorstwa, Ruch Prawniczy, Ekonomiczny i Socjologiczny 2005/LXVII/3, s. 191-199.

Malaquias Pedro F., Sofia Leite B., Securitisation under the Portuguese Securitisation Law, w: The international comparative legal guide to securitisation, GLG, 2005, s. 193-203.

Reksa Lukasz, Sekurytyzacja wierzytelności na rynkach międzynarodowych, Bank i Kredyt 2004/2, s. 59-70. 
Reksa Lukasz, Sekurytyzacja w krajach Unii Europejskiej oraz w polskim systemie bankowym. Wyniki ankiety badawczej, KNF, Warszawa 2007.

Roberts Blake, Pioneering Securitisation in the French Market, w: Zoe Shaw (red.), International securitisation. The scope, development and future outlook for asset-backed finance, Berlin-London 1990, s. 127-133.

Schwarcz Steven L., The Alchemy of Asset Securitization, Stanford Journal of Law, Business \& Finance 1994/1:133/1, s. 133-154.

Zombirt Jolanta, Sekurytyzacja w Bazylei - nadal dużo niewiadomych, Bank 12/2002-1/2003, s. 34-38.

Zombirt Jolanta, Sekurytyzacja w Bazylei (cz. II), Bank 2003/2, s. 22-25.

Zombirt Jolanta, Sekurytyzacja w Nowej Umowie Kapitałowej, Prawo Bankowe 2003/7-8, s. 31-50.

\section{Strony internetowe}

http://orka.sejm.gov.pl/proc4.nsf; stan na 1.02.2017 r.

http://orka.sejm.gov.pl/proc4.nsf druk 2080; stan na 1.02.2017 r.

https://alebank.pl/zielone-swiatlo-dla-subpartycypacji-w-bankach/?id=38578\&catid=625; stan na 1.02.2017 r.

https://biznes.newseria.pl/komunikaty/bankowosc/trudne-zycie-funduszy,b2019726180; stan na 1.02.2017 r.

Michał NAJMAN

\section{SPECIFICS OF SECURITIZATION}

( Sum mary)

Article refers to the concept of securitization in the Polish commercial law. The aim of this publication is to present the stages of dissemination of securitization in the course of trade, its legal nature, stable ingredients, the objective and subjective admissibility, the rights and obligations of the parties and other entities participating in securitization, the economic purpose, the possible impact on the financial undertaking which is party to the securitization, as well as the realization spread of securitization in Poland due to the possible benefit of its conduct, and hence, the need to regulate by law its conclusion. The article has been omitted specific issues of legal regulation of securitization carried out in Poland, due to their residualness, excessive formalism and mismatch to the realities of the current economic turnover. In conclusion, the author presents proposals de lege ferenda about the legal regulation of securitization in Poland in relation to non enacted draft law on securitization of 2003.

Keywords: commercial law; securitization; trade agreement; objective and subjective admissibility of securitization 